\title{
Necrotising Fasciitis: Appearances Can Be Deceptive
}

\author{
Shanthakumar Shivalingappa ${ }^{1}$, KN Manjunath ${ }^{1} *$, Veena Waiker ${ }^{1}$, M Kumaraswamy ${ }^{1}$, \\ Udayashankar Odeyar ${ }^{2}$
}

1. Department of Plastic and Reconstructive Surgery, Ramaiah Medical College, Bangalore, India;

2. Plastic Surgeon, Bangalore, India

*Corresponding Author:

KN Manjunath, Department of Plastic and Reconstructive Surgery, Ramaiah Medical College, Bangalore, India.

Tel/Fax: +91-9535971056

Email:drknmanjunath@gmail.com

Received: April 26, 2020

Revised: October 9, 2020

Accepted: October 17, 2020

\section{ABSTRACT}

\section{BACKGROUND}

Necrotizing fasciitis is a potentially fatal infection of $\beta$ hemolytic Group-A Streptococcus, often occurring in patients with other comorbidities, but can occur in healthy individuals as well. It commonly affects the extremities, perineum, and abdominal wall. The aim of this study was to highlight various presentations of necrotizing fasciitis in unusual anatomical sites with delayed diagnosis and treatment.

\section{METHODS}

In a retrospective analysis, seven cases of unusual presentations of necrotizing fasciitis were enrolled during a period of five years treated in a tertiary centre.

\section{RESULTS}

The patients were between 23 and 80 years. Four were males and three were females. Four out of seven were diabetic. All patients had septicemia (hypovolemic shock, with leucocytosis, thrombocytopenia and deranged coagulation parameters) on admission in the intensive care unit. All seven patients had minimal cutaneous manifestation and the remote primary pathology was diagnosed in two patients. Six patients out of seven survived and the morbid state continued in one patient in view of malignancy of rectum in one patient. The overall outcome was satisfactory in five out of seven cases.

\section{CONCLUSION}

Pain disproportionate to the local inflammation with florid constitutional symptoms should raise suspicion of necrotizing fasciitis. Early diagnosis, of stabilization of hemodynamics, emergency fasciotomy, staged debridement and the initiation of broad spectrum antibiotics reduced the morbidity and mortality. The disease may manifest with uncommon presentations and sometimes lead to the diagnosis of primary aetiology.

\section{KEYWORDS}

Necrotising fasciitis; Streptococcus; Carcinoma; Reconstruction

Please cite this paper as:

Shivalingappa S, Manjunath KN, Waiker V, Kumaraswamy M, Odeyar U. Necrotising Fasciitis: Appearances Can Be Deceptive. World J Plast Surg.2021;10(1):43-52.doi: 10.29252/wjps.10.1.43

\section{INTRODUCTION}

The discovery of necrotising fasciitis dates back to Hippocrates in $5^{\text {th }}$ century B.C. and Wilson in $1952 .{ }^{1}$ The early clinical diagnostic challenge still lurks despite adjunct radiological and laboratory investigations; hence, the morbidity and mortality are high, even today. Necrotizing fasciitis is a rapidly progressive spreading inflammation caused by Group-A $\beta$ hemolytic Streptococcus, but may be polymicrobial. ${ }^{2,3}$ The major risk factors are diabetes, peripheral vascular disease, old age and immune-compromised status but can primarily affect healthy individual too. ${ }^{4}$ 
Surgical procedures, post-cesarean section and minor wounds are usual pre-disposing factors. The extremities, abdominal wall and perineum are more commonly affected than other regions. ${ }^{5}$ The organism gains entry through a breech in the skin and initiates local infection seen as skin blisters. Infection rapidly progresses along fascial planes involving large surface areas and depth. Muscle compartments are affected as a consequence of spreading infection, but the cutaneous manifestations are limited. Constitutional symptoms like severe pain out of proportion to the local inflammation in the affected area, high grade fever, vomiting and diarrhea should raise suspicion of necrotizing fasciitis. Successful outcome of treatment depends on differentiating limb threatening infection like necrotizing fasciitis, from non-limb-threatening superficial cellulitis. ${ }^{6}$

Though the incidence of necrotizing fasciitis is high, a retrospective observation of few patients with unusual presentations and involvement of uncommon anatomical regions has enabled us to view the disease with a much wider perspective which would otherwise be missed. The aim of presenting this study was to highlight the uncommon acute presentations of necrotizing fasciitis at uncommon sites, which may sometimes downplay the severity and mislead the diagnosis, thereby delaying the time of surgical intervention resulting in increased morbidity and mortality. Also to emphasize on a thorough clinical examination supported by laboratory and imaging studies in patients with uncommon presentations, which would throw light on unusual etiological factors that enables the surgeon to customize the management.

\section{MATERIALS AND METHODS}

All patients admitted from 2009 to 2014 were included in the study. The patients with the diagnosis of necrotizing fasciitis in unusual sites were enrolled. On admission, thorough history was taken and details of previous hospitalisation were obtained. The local manifestations were recorded. The findings during the surgery were noticed. Patient's sepsis parameters were prepared. The severity of infection in comparison to the amount of local tissue damage was studied. Management was done with intravenous clindamycin, $600 \mathrm{mg}$ twice a day for 48 hours, and then continued with $300 \mathrm{mg}$ of the medication $12^{\text {th }}$ hourly for one week to ten days in all patients in addition to other antibiotics according to the sensitivity report.

All procedures performed in the study involving human participants were in accordance with the ethical standards and with the 1964 Helsinki declaration and its later amendments or comparable ethical standards. For retrospective studies, a formal consent was not required and provided. Surgical management included multiple surgical debridements. The features suggestive of necrotising fasciitis like necrotic fascia and easy separation of the fascia from the overlying skin were looked for. On easy separation of the skin from the fascia, the diagnosis of necrotising fasciitis was confirmed. Factors affecting the recovery of the patients like duration of hospital stay, time taken for sepsis parameters to improve, and the number of undertaken reconstructive procedures were all recorded. The patient was deemed recovered, when the patient was fit for discharge. The continuous variables were described as mean and median with standard deviations.

\section{RESULTS}

The age of the affected patients was not limited to one group. The youngest patient was 23 years old and the oldest was 83 years old. Before coming to our hospital, 7 patients $(100 \%)$ had history of treatment outside the hospital. Patients were referred to our hospital after a median time of 5.8 days from the time of onset of symptoms. Four out of 7 patients $(57.1 \%)$ were diabetics and had sustained trivial injuries. All patients were diagnosed as cellulitis and took conservative treatment in other hospital (Table 1). All seven patients $(100 \%)$ had septicemia on admission with deranged laboratory parameters (Table 2).

On exploration, non-viable deep tissue and fascia were found through the wounds in all patients (100\%); hence, the diagnosis of necrotizing fasciitis was confirmed.

On debridement, all patients had necrosis of superficial and deep fascia, epimysium and fascial coverings of neurovascular structures that could be easily dissected and excised (Table 3). Group a Beta hemolytic Streptococcus was isolated in two patients, polymicrobial in three, one had methicillin sensitive Staphylococcus aureus and there was no growth in one patient. 
Table 1: Primary diagnosis at peripheral hospital and management

\begin{tabular}{|c|c|c|c|c|c|c|}
\hline Name & $\begin{array}{c}\text { Age } \\
\text { (Years) }\end{array}$ & Sex & $\begin{array}{l}\text { Reported to } \\
\text { hospital }\end{array}$ & $\begin{array}{l}\text { Primary diagnosis in } \\
\text { peripheral hospital }\end{array}$ & $\begin{array}{c}\text { Primary } \\
\text { treatment } \\
\text { in peripheral } \\
\text { hospital }\end{array}$ & Co-morbidities \\
\hline $\begin{array}{l}\text { C1 } \\
\text { (Figure 1) }\end{array}$ & 23 & $\mathrm{~F}$ & $\begin{array}{l}\text { After } 2 \text { days fever, } \\
\text { pain in left breast }\end{array}$ & Breast abscess & I \& D & Local factors \\
\hline $\begin{array}{l}\mathrm{C} 2 \\
\text { (Figure 2) }\end{array}$ & 50 & M & $\begin{array}{c}\text { After } 2 \text { days } \\
\text { Fever, pain in neck }\end{array}$ & $\begin{array}{l}\text { Laceration Left side } \\
\text { chin and cellulitis }\end{array}$ & Antibiotics & Diabetes mellitus \\
\hline $\mathrm{C} 3$ & 55 & $\mathrm{~F}$ & $\begin{array}{l}\text { After } 4 \text { days fever, } \\
\text { pain, swelling in } \\
\text { perineum }\end{array}$ & $\begin{array}{l}\text { Perianal abscess, } \\
\text { cellulitis }\end{array}$ & $\begin{array}{c}\text { I \&D, } \\
\text { Antibiotics }\end{array}$ & Malignancy \\
\hline $\mathrm{C} 4$ & 80 & M & $\begin{array}{l}\text { After } 2 \text { days pain in } \\
\text { left eye, fever }\end{array}$ & $\begin{array}{l}\text { Cellulitis following } \\
\text { laceration on the upper } \\
\text { eye lid }\end{array}$ & Antibiotics & $\begin{array}{l}\text { Diabetes mellitus, } \\
\text { hypertension, left } \\
\text { hemiparesis }\end{array}$ \\
\hline $\mathrm{C} 5$ & 40 & M & $\begin{array}{l}\text { After } 4 \text { days pain in } \\
\text { the back and left } \\
\text { foot, fever }\end{array}$ & $\begin{array}{l}\text { Gangrene, cellulitis of } \\
\text { left great toe and back }\end{array}$ & $\begin{array}{c}\text { I \&D, } \\
\text { Antibiotics }\end{array}$ & $\begin{array}{l}\text { Diabetes mellitus } \\
\text { and anasarca }\end{array}$ \\
\hline $\begin{array}{l}\text { C6 } \\
\text { (Figure 3) }\end{array}$ & 52 & $\mathrm{~F}$ & $\begin{array}{l}\text { After } 4 \text { days pain, } \\
\text { facial edema, fever }\end{array}$ & $\begin{array}{l}\text { Scalp ulcer with } \\
\text { cellulitis of face }\end{array}$ & $\begin{array}{l}\text { Antibiotics, } \\
\text { conservative } \\
\text { management } \\
\text { for facial } \\
\text { cellulitis }\end{array}$ & Diabetes mellitus \\
\hline $\mathrm{C} 7$ & 55 & M & $\begin{array}{l}\text { Patient did not visit } \\
\text { any hospital for } 10 \\
\text { days. }\end{array}$ & - & $\begin{array}{l}\text { Treated at } \\
\text { home with } \\
\text { analgesics and } \\
\text { anti-pyretic. }\end{array}$ & Nil \\
\hline
\end{tabular}
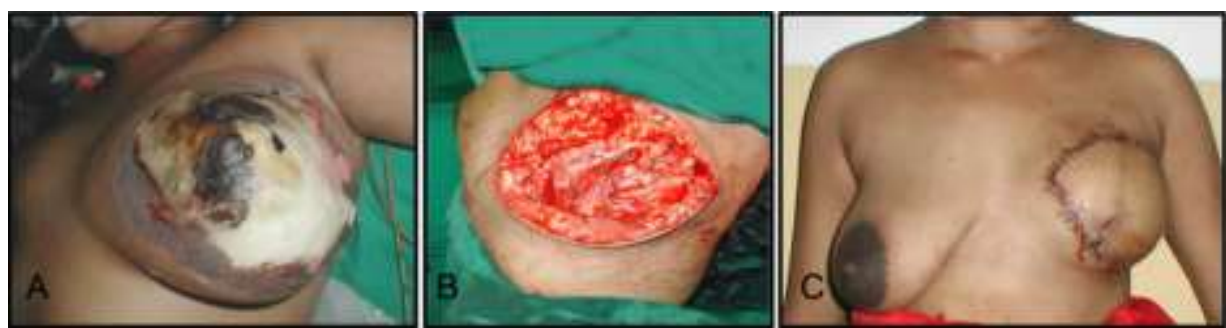

Fig. 1: A 23 years old patient referred to the hospital After 2 days of fever and pain in left breast with primary diagnosis of breast abscess undergoing I\&D treatment.

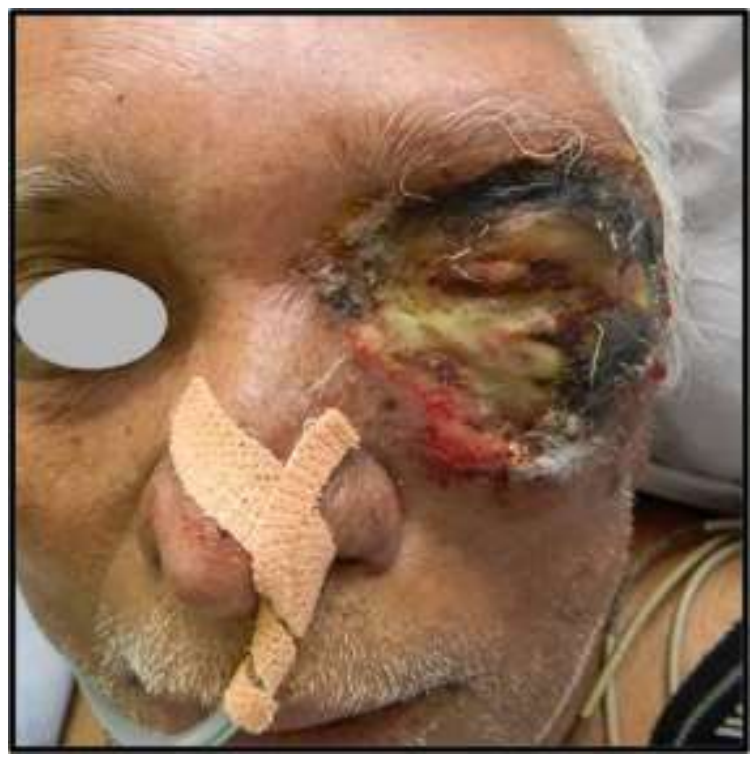

Fig. 2: A 50 years old male patient referred to the hospital after 2 days of fever and pain in the neck and a previous history of diabetes mellitus with primary diagnosis of laceration in the left side chin and cellulitis receiving antibiotics for treatment. 

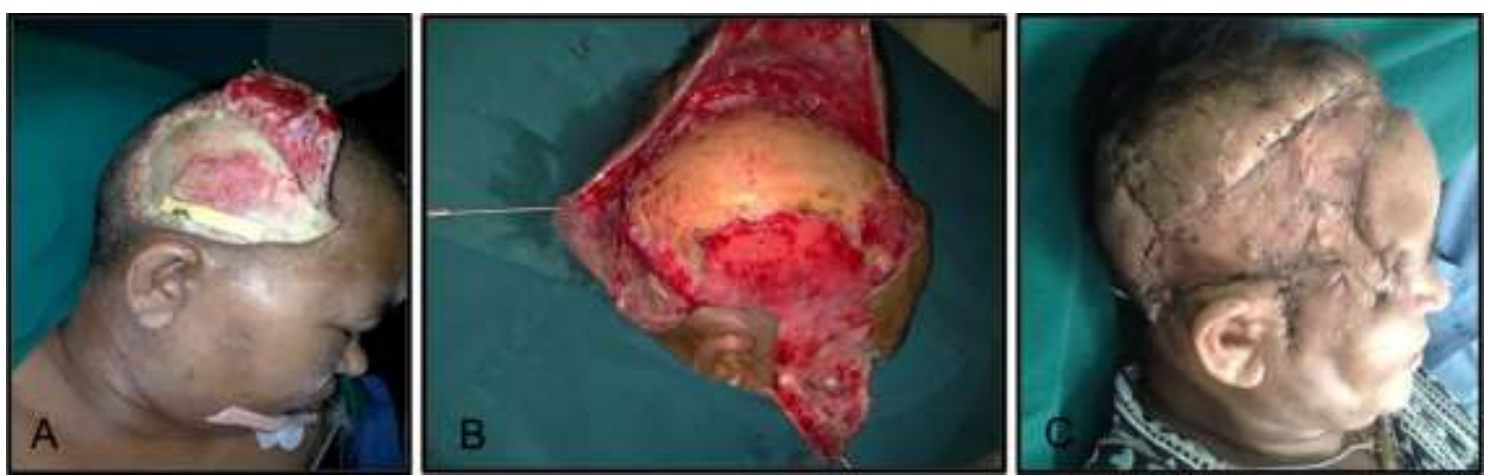

Fig. 3: A 52 years old female patient referred to the hospital after 4 days of fever, pain and facial edema and a previous history of diabetes mellitus with primary diagnosis of scalp ulcer and face cellulitis receiving antibiotics and conservative management for facial cellulitis.

Table 2: Lab parameters on admission to our hospital.

\begin{tabular}{|c|c|c|c|c|c|c|c|c|}
\hline Name & $\begin{array}{l}\mathbf{H b} \\
\mathrm{g} / \mathbf{d L}\end{array}$ & $\begin{array}{l}\text { TC } \\
\text { Cells/cu.mm }\end{array}$ & Platelet & $\begin{array}{l}\text { APTT } \\
\text { secs }\end{array}$ & Creat & $\begin{array}{l}\text { Alb } \\
\text { G/dL }\end{array}$ & Culture & Radiology \\
\hline $\mathrm{C} 1$ & 8 & 29,990 & 40,000 & 40.1 & 2.0 & 1.8 & $\begin{array}{l}\text { Group A Beta } \\
\text { haemolytic. } \\
\text { Streptococcus }\end{array}$ & \\
\hline $\mathrm{C} 2$ & $\begin{array}{l}13.1 \\
\text { pev-41 }\end{array}$ & 20,000 & 10,000 & 53.1 & 1.8 & 2.5 & $\begin{array}{l}\text { Group A Beta } \\
\text { haemolytic } \\
\text { Streptococcus }\end{array}$ & $\begin{array}{l}\text { MRI } \\
\text { Inflammation neck and chest. } \\
\text { Thrombosis of external jugular } \\
\text { vein }\end{array}$ \\
\hline $\mathrm{C} 3$ & 5.4 & 17,700 & 80,000 & 39 & & 1.4 & $\begin{array}{l}\text { K. oxytoca } \\
\text { E. Coli } \\
\text { Gram positive cocci }\end{array}$ & \\
\hline $\mathrm{C} 4$ & 7.0 & 19,000 & $1,00,000$ & 36.4 & 1.9 & 2.0 & No growth & $\begin{array}{l}\text { C.T. scan } \\
\text { Soft tissue swelling of periorbital, } \\
\text { prefrontal, premaxillary, } \\
\text { perizygomaticareas. } \\
\text { C.T. scan brain, old subcortical } \\
\text { lacunar infarct. } \\
\text { M.R.I. of cavernous sinus region, } \\
\text { normal. }\end{array}$ \\
\hline C5 & 8 & 12,000 & 60,000 & 41.3 & 2.0 & 2.0 & $\begin{array}{l}\text { K. pneumonia, } \\
\text { Acinitobacter, } P . \\
\text { aeruginosa, } \\
\text { Enterobacter, } \\
\text { Saureus (MSSA) }\end{array}$ & $\begin{array}{l}\text { C.T. scan abdomen, chronic } \\
\text { pancreatitis }\end{array}$ \\
\hline C6 & 9.7 & 23,420 & $\begin{array}{l}1.93 \\
\text { lakhs }\end{array}$ & 39.5 & 1.07 & 1.22 & $\begin{array}{l}\text { K. pneumonia } \\
\text { Acinitobacter }\end{array}$ & \\
\hline C7 & 1.4 & 44.8 & 1.57 & & 1.6 & & MSSA & $\begin{array}{l}\text { Bilateral minimal pleural effusion, } \\
\text { fluid in left ischiorectal fossa, } \\
\text { diffuse subcutaneous oedema in left } \\
\text { gluteal region, dilated proximal } \\
\text { small bowel loops with collapse of } \\
\text { distal ileal loops suggestive of acute } \\
\text { intestinal obstruction. }\end{array}$ \\
\hline
\end{tabular}

Table 3: Late clinical presentation at our hospital.

\begin{tabular}{lccccc}
\hline Name & $\begin{array}{c}\text { Day of } \\
\text { presentation }\end{array}$ & Extent & HR/min & BP mm/Hg & Temp \\
& 0.F & \\
\hline C1 & After 1 week & Left Breast & 110 & $90 / 50$ & 102 \\
C2 & After 5 days & Right side of neck and chin & 100 & $100 / 74$ & 100 \\
C3 & After 1 week & Lower abdomen and right thigh & 100 & $90 / 60$ & $100 / 50$ \\
C4 & After 2 days & Right eyelids and peri-orbital area & 106 & $100 / 60$ & 110 \\
C5 & After 1 week & Back of trunk, left leg and great toe & 110 & $100 / 80$ & 101 \\
C6 & After 1 week & Right fronto-temporo-parieto-occipital areas and face & 110 & $116 / 70$ & 101 \\
C7 & After 10 days & Left ischial area, scrotum, both inguinal regions and & 110 & 98.6 \\
& & lower abdominal wall up to umbilicus & & \\
\hline
\end{tabular}


This was followed by wound bed preparation and resurfacing after mean time of 9.8 days. Multiple surgeries for optimization of wound bed were shown in Table 4. Finally, out of 7 patients, six survived and one was expired due to MODS.
Out of the seven patients, six survived and the patient with associated chronic pancreatitis was expired due to septicemia and acute respiratory distress syndrome (Table 4).

Table 4: Management at our hospital.

\begin{tabular}{|c|c|c|c|c|c|}
\hline Name & Surgical procedure & $\begin{array}{l}\text { Day of wound } \\
\text { cover }\end{array}$ & Outcome & Uncommon presentation & $\begin{array}{l}\text { Uncommon } \\
\text { site }\end{array}$ \\
\hline $\mathrm{C} 1$ & $\begin{array}{l}\text { Left mastectomy and } \\
\text { reconstruction with RT } \\
\text { pedicled TRAM flap }\end{array}$ & After 2 days & Recovered well. & $\begin{array}{l}\text { Lactating woman with Cracks } \\
\& \text { fissures of nipple on breast } \\
\text { pump }\end{array}$ & Breast \\
\hline $\mathrm{C} 2$ & $\begin{array}{l}\text { Staged debridements } \\
\text { and SSG }\end{array}$ & After 7 days & $\begin{array}{l}\text { Hoarseness of } \\
\text { voice recovered } \\
\text { by } 3 \text { months }\end{array}$ & $\begin{array}{l}\text { Superficial } 2 \mathrm{~cm} \text { laceration on } \\
\text { chin while shaving at barber } \\
\text { shop }\end{array}$ & $\begin{array}{l}\text { Neck } \\
\text { chin }\end{array}$ \\
\hline $\mathrm{C} 3$ & $\begin{array}{l}\text { Permanent colostomy , } \\
\text { multiple } \\
\text { debridements+SSG }\end{array}$ & After10 days & $\begin{array}{l}\text { Treated } \\
\text { conservatively } \\
\text { with permanent } \\
\text { colostomy }\end{array}$ & $\begin{array}{l}\text { Presented as perianal abscess, } \\
\text { PR-Growth in rectum, } \\
\text { HPE, Adenocarcinoma of } \\
\text { rectum }\end{array}$ & - \\
\hline $\mathrm{C} 4$ & $\begin{array}{l}\text { Multiple conservative } \\
\text { debridement of upper } \\
\text { and lower eyelids and } \\
\text { periorbital area+SSG }\end{array}$ & After 10 days & Recovered & $\begin{array}{l}\text { Superficial laceration on eyelid } \\
\text { leading to full thickness } \\
\text { necrosis of orbital area }\end{array}$ & $\begin{array}{l}\text { Eyelids and } \\
\text { peri-orbital } \\
\text { area }\end{array}$ \\
\hline $\mathrm{C} 5$ & $\begin{array}{l}\text { Multiple debridement, } \\
\text { disarticulation of left } \\
\text { great toe, tibialis anterior } \\
\text { muscle flap to cover } \\
\text { middle } 3^{\text {rd tibia+ SSG on }} \\
\text { back and left leg }\end{array}$ & After 21 days & Expired & $\begin{array}{l}\text { Associated Chronic } \\
\text { pancreatitis, hypoalbuminemia, } \\
\text { anasarca } \\
\text { Extensive, pale, edematous } \\
\text { wounds which never healed. } \\
\text { Flap and SSG failed. }\end{array}$ & $\begin{array}{l}\text { Back } \\
\text { trunk }\end{array}$ \\
\hline C6 & $\begin{array}{l}\text { Multiple debridement, } \\
\text { scalp advancement flap } \\
\text { and SSG }\end{array}$ & After 9 days & $\begin{array}{l}\text { Scar contracture } \\
\text { lateral canthus } \\
\text { of right eye }\end{array}$ & $\begin{array}{l}\text { Undetected painless post } \\
\text { traumatic necrotic patch in } \\
\text { right temporoperietal region of } \\
\text { scalp with extensive necrosis of } \\
\text { pericranium, parotid fascia and } \\
\text { SMAS }\end{array}$ & $\begin{array}{l}\text { Scalp and } \\
\text { SMAS }\end{array}$ \\
\hline C7 & $\begin{array}{l}\text { Multiple } \\
\text { debridement+SSG }\end{array}$ & $\begin{array}{l}\text { Extensive } \\
\text { wound } \\
\text { debridement } \\
\text { and split skin } \\
\text { graft. }\end{array}$ & Recovered well. & $\begin{array}{l}\text { Presented with features of acute } \\
\text { abdomen }\end{array}$ & - \\
\hline
\end{tabular}

\section{DISCUSSION}

Necrotising fasciitis though rare, is known for its high morbidity and mortality. Its similarity to other cutaneous inflammation poses a huge diagnostic challenge even today. However, early diagnosis is the key for better outcome as early initiation of appropriate antibiotic and surgical therapy. Etiological factors are often trivial like trauma, cutaneous wounds, drug injections, abscesses, tineapedis in the lower extremity, and animal or insect bites. $^{7}$ Hematogenous spread of microorganisms from a distant site of infection can sometimes be detected even with small injuries. ${ }^{8}$

The organisms usually enter the body through a minor wound like our patients $(\mathrm{C} 1, \mathrm{C} 2$ and $\mathrm{C} 4)$ who had small wounds on the breast, chin and eyelid, respectively; which is consistent with other studies. ${ }^{9}$ The disease spreads rapidly along tangential planes through fascia with extensive undermining with apparently normal looking skin. The condition evolves, through the following clinical stages which is helpful in assessment of severity and progress of the disease. Stage 1: Pain, tenderness and warm skin; Stage 2: Blister or bulla formation which signals the onset of critical skin ischemia; and Stage 3: Onset of tissue necrosis characterized by the 'hard signs' of necrotizing soft tissue infection, such as hemorrhagic bullae, skin anesthesia and frank skin gangrene. ${ }^{7}$

The classical systemic manifestations like high fever, severe excruciating pain in the affected 
region and prostration should raise suspicion of necrotizing fasciitis in the early stages as diagnosis is often missed in this stage. ${ }^{10}$ All patients were diagnosed to have cellulitis when they first attended the referral hospital. Even in other studies, the majority were diagnosed as cellulitis with a differential diagnosis of erysipelas, myonecrosis, lymphedema, eosinophilic fasciitis, phlegmasia cerulean dolens, or myxedema. ${ }^{11-13}$ Hence, the management in the initial stages was less aggressive in our patients which increased the morbidity.

As described in literature, hypovolemic shock, tachycardia, acidosis, anemia, thrombocytopenia, dyselectrolytemia, hypoalbuminemia, acute renal failure, adult respiratory distress syndrome, altered liver function, deranged coagulation, disseminated intravascular coagulation; multi- organ failure and death are consequences of bacterial systemic toxicity. ${ }^{14}$ All patients were in sepsis by the time they presented to us. The severity of disease severity was dependent on the virulence of the organism and has been classified as Type I: Polymicrobial, where a mixed aerobic and anaerobic infection is the cause (which could be due to Acetinobacter baumanii and rarely Vibrio spp. In this situation, blood cultures are positive $\sim 20 \%$ of the time. ${ }^{14}$ Three of patients (C3, C5 and C6) had polymicrobial infection.

Type II: Monomicrobial infection is due to Group A Streptococcus and occasionally methicillinresistant Staphylococcus aureus (MRSA). Type II NF is complicated by toxic shock syndrome in up to $50 \%$ of cases with positive blood cultures in $\sim 60 \% .{ }^{15}$ Two of our patients ( $\mathrm{C} 1$ and $\mathrm{C} 2$ ) were affected by Streptococcus $\beta$ hemolyticus who were in toxic shock. The patient $\mathrm{C} 4$ was also toxic, but the organism could not be isolated as repeated wound cultures showed no growth. Type III: Gas gangrene infections are most commonly caused by the anaerobe Clostridium perfringens. ${ }^{15}$

Some of the scoring systems like the retrospective risk score called LRINEC (Laboratory Risk Indicator for Necrotizing Fasciitis) was calculated by summating values of CRP, total count, hemoglobin, sodium, creatinine and glucose that are complimentary to diagnosis. However, this is not a substitute for clinical judgement. ${ }^{16}$ Laboratory and culture tests have correlative clinical significance. ${ }^{7}$ Imaging studies like computed tomography (CT) is more sensitive and specific in identifying gas and magnetic resonance imaging (MRI) is more sensitive than CT for detecting edema fluid and thickening of fascia. However, it is difficult to differentiate between cellulitis and necrotizing fasciitis with imaging. The patient $\mathrm{C} 2$ underwent MRI to assess the depth of the infection in the mediastinal area and in patient C4, CT scan of brain was done to examine the cavernous sinus area. ${ }^{17-23}$

We also found that these investigations were complimentary to clinical evaluation and were not specific for necrotising fasciitis. Finger test is a simple, bedside diagnostic test as described by Andreasen et al. A2 cm incision is made down to the deep fascia under local anesthesia in the area of tenderness or blister. If probing at the level of superficial fascia is undertaken, it reveals lack of bleeding, foul smelling dishwater pus and minimal tissue resistance to finger dissection and it is diagnostic of necrotizing fasciitis; which mandates further debridement. ${ }^{7,24}$

The primary site of pathology is in the superficial fascia that later is spread to the dermis and deep fascia due to thrombosis and suppuration of the veins and arteries coursing through the fascia. ${ }^{25}$ All patients had minimal necrosis of overlying skin, but showed thrombosis of vessels and suppuration of fascia and epimysium. Proximal extension of infection along fascia covering neurovascular structures was evident on surgical exploration. The control of infection was indicated clinically by a gradual reduction of constitutional symptoms, bacterial colony count, and improvement of serum albumin and electrolytes. Reduction in wound discharge and edema with growth of vascularized granulation tissue were indicators of progress of the wound bed towards optimisation. All patients were treated with intravenous clindamycin in combination with penicillin group/third generation cephalosporin in addition to surgical excision; which was very effective in reducing the toxic effects within 48 hours except in patients $\mathrm{C} 5$ and $\mathrm{C} 6$. $^{24,26}$

Necrotizing fasciitis is more frequent in abdominal wall, perineum and extremities. Involvement of the head and neck structures and especially the scalp is rare in view of good vascularity. In our patients, uncommon areas like breast, chest and neck, back of trunk, orbital area, scalp and abdominal wall were affected and their unusual presentations also misled the diagnosis. Necrotising fasciitis of lactating breast is rare and only a few cases have been reported. It mimics breast abscess and sometimes even carcinoma of breast. Diagnosis may be delayed as the breast and 
fatty tissue may obscure the inflammation of the pectoral fascia.

As our patient (C1) was mis-diagnosed to have breast abscess, only small incisions were made for drainage before reporting to our hospital after one week. The delay in wound excision led to widespread infection and ultimately major tissue loss. Literature search revealed the use of split skin graft for resurfacing the post-mastectomy defect; whereas in our case, the breast was reconstructed with contralateral transverse rectus abdominis myocutaneous flap after controlling the infection. It gave psychologically satisfying results to our young patient who was a victim of this benign yet devastating condition. ${ }^{27-33}$

The usual nidus of infection for neck and chest areas is the teeth and tonsils. ${ }^{34-42}$ It is associated with high mortality. Minor trauma in our diabetic patient (C2) led to a host of response in the face and neck area. This type of presentation has not been reported in the literature. The involvement of perineum, thigh and abdominal wall similar to Fournier's synergistic gangrene is common. ${ }^{43}$ In our patient, rectal examination was informative in establishing the cause of necrotizing fasciitis. It was the local manifestation of an end stage disease, i.e., carcinoma of rectum. Necrotizing fasciitis following C-section has been reported following the administration of NSAIDs in the immediate postoperative period..$^{44,45}$

Periocular necrotising fasciitis is unusual due to the excellent blood supply of the facial region and only a few cases have been reported. ${ }^{46}$ In the early stages, it may be mistaken for cellulitis. ${ }^{47,48} \mathrm{~A}$ conservative debridement helped to retain the eyelid structures as much as possible. ${ }^{49,50}$ Though necrotizing fasciitis of the back of trunk and leg is not uncommon, association of chronic pancreatitis as in our case is unusual. Wounds could never be optimized and healing was poor, despite multiple debridements (in view of mal-absorption and malnutrition secondary to chronic pancreatitis), which were responsible for prolonged morbidity and mortality in our patient.

Necrotizing fasciitis of scalp is rare, but can sometimes occur due to odontogenic infections. 21, 44, 51-59 But in our patient, it followed trauma. The disease spread rapidly and on surgery, there was extensive necrosis of the pericranium and SMAS with induration of ear and neck; which took unusually long time to settle despite multiple debridements. Necrotising fasciitis of abdominal wall presenting with features of sub-acute intestinal obstruction as in (C7) has not been reported. The overall outcome was good in our patients as six out of seven survived, despite of septicemia and associated co-morbidities. The major hindrances to the effective treatment are accurate diagnosis and detection of underlying primary cause, if there are any. Though there is no antidote to arrest the chain of host response, which prolongs morbidity and risk of mortality, the disease can still be brought under control with aggressive surgical management and appropriate antibiotics. ${ }^{60-62}$

\section{CONCLUSION}

Necrotising fasciitis is a life threatening infection. Often it begins following a minor etiology. The diagnosis is often delayed due to paucity of symptoms and cutaneous findings. It is often treated as a minor disease process. An early accurate diagnosis can be made with a high index of suspicion and bedside diagnostic confirmative tests, i.e. Andersen's finger test. Sometimes involvement of unusual clinical sites and involvement of uncommon anatomical region may mislead the diagnosis in initial stages. In some patients, it may be the local manifestation of a systemic disease; which brings the hidden primary pathology to notice. In such situations, the treatment of primary cause is also mandated. The mortality and morbidity of the disease is high but if detected early and treated appropriately, good outcome can be expected.

\section{CONFLICT OF INTEREST}

The author has no conflicts of interest to declare.

\section{REFERENCES}

1 Descamps V, Aitken J, Lee MG. Hippocrates on necrotising fasciitis. Lancet 1994;344:556. doi: 10.1016/s0140-6736(94)91956-9.

2 Bellapianta JM, Ljungquist $\mathrm{K}$, Tobin E, Uhl R. Necrotizing fasciitis. $J$ Am Acad Orthop Surg 2009;17:174-82. doi: 10.5435/00124635200903000-00006.

3 Elliott D, Kufera JA, Myers RA. The microbiology of necrotizing soft tissue infections. Am J Surg 
2000;179:361-6. doi: 10.1016/s00029610(00)00360-3.

4 Smith SR, Aljarabah M, Ferguson G, Babar Z. Necrotizing fasciitis following saphenofemoral junction ligation with long saphenous vein stripping: a case report. $J$ Med Case Rep 2010;4:161. doi: 10.1186/1752-1947-4-161.

5 Roje Z, Roje Z, Matic D, Librenjak D, Dokuzovic S, Varvodic J. Necrotizing fasciitis: literature review of contemporary strategies for diagnosing and management with three case reports: torso, abdominal wall, upper and lower limbs. World $J$ Emerg Surg 2011;6:46. doi: 10.1186/1749-7922-646.

6 Wong $\mathrm{CH}$, Wang YS. The diagnosis of necrotizing fasciitis. Curr Opin Infect Dis 2005;18:101-6. doi: 10.1097/01.qco.0000160896.74492.ea.

7 Jones J. Investigation on the nature, causes and treatment of hospital gangrene as it prevails in the confederate armies 1861-1865. Surgical memoirs of the war of rebellion New York: Sanitary Commission 1871. In: Hasting Hamilton F, editors. Surgical memoirs of the war of rebellion. New York: Sanitary Commission; 1871.

8 Taviloglu K, Yanar $H$. Necrotizing fasciitis: strategies for diagnosis and management. World $J$ Emerg Surg 2007;2:19. doi: 10.1186/1749-7922-219.

9 Wall DB, Klein SR, Black S, de Virgilio C. A simple model to help distinguish necrotizing fasciitis from nonnecrotizing soft tissue infection. Journal of the American College of Surgeons 2000;191:227-31. doi: 10.1016/S10727515(00)00318-5.

10 Hasham S, Matteucci P, Stanley PR, Hart NB. Necrotising fasciitis. BMJ 2005;330:830-3. doi: 10.1136/bmj.330.7495.830.

11 Wall DB, de Virgilio C, Black S, Klein SR. Objective criteria may assist in distinguishing necrotizing fasciitis from nonnecrotizing soft tissue infection. The American Journal of Surgery 2000;179:17-20. doi: 10.1016/S00029610(99)00259-7.

12 Wong $\mathrm{CH}$, Tan SH. Subacute necrotising fasciitis. The Lancet 2004;364:1376. doi: 10.1016/S01406736(04)17197-3.

13 Charnot-Katsikas A, Dorafshar AH, Aycock JK, David MZ, Weber SG, Frank KM. Two cases of necrotizing fasciitis due to Acinetobacter baumannii. J Clin Microbiol 2009;47:258-63. doi: 10.1128/JCM.01250-08.
14 Meleney FL. Hemolytic streptococcus gangrene. Archives of Surgery 1924;9:317-64. 10.1001/archsurg.1924.01120080083007.

15 Wong CH, Khin LW, Heng KS, Tan KC, Low CO. The LRINEC (Laboratory Risk Indicator for Necrotizing Fasciitis) score: a tool for distinguishing necrotizing fasciitis from other soft tissue infections. Crit Care Med 2004;32:1535-41. doi: 10.1097/01.ccm.0000129486.35458.7d.

16 Tsai CC, Lai CS, Yu ML, Chou CK, Lin SD. Early diagnosis of necrotizing fasciitis by utilization of ultrasonography. Kaohsiung $J$ Med Sci 1996; 12:235-40.

17 Schmid MR, Kossmann T, Duewell S. Differentiation of necrotizing fasciitis and cellulitis using MR imaging. AJR Am J Roentgenol 1998;170:615-20. doi: 10.2214/ajr.170.3.9490940.

18 Brothers TE, Tagge DU, Stutley JE, Conway WF, Del Schutte H, Jr., Byrne TK. Magnetic resonance imaging differentiates between necrotizing and nonnecrotizing fasciitis of the lower extremity. $J \mathrm{Am}$ Coll Surg 1998;187:416-21. doi: 10.1016/s10727515(98)00192-6.

19 Arslan A, Pierre-Jerome C, Borthne A. Necrotizing fasciitis: unreliable MRI findings in the preoperative diagnosis. Eur J Radiol 2000;36:139-43. doi: 10.1016/s0720-048x(00)00164-9. doi: 10.1016/S0720-048X(00)00164-9.

20 Wysoki MG, Santora TA, Shah RM, Friedman AC. Necrotizing fasciitis: CT characteristics. Radiology 1997;203:859-63.

doi: 10.1148/radiology.203.3.9169717.

21 Becker M, Zbaren P, Hermans R, Becker CD, Marchal F, Kurt AM, Marre S, Rufenacht DA, Terrier F. Necrotizing fasciitis of the head and neck: role of CT in diagnosis and management. Radiology 1997;202:471-6. doi: 10.1148/radiology.202.2.9015076.

22 Wysoki MG, Santora TA, Shah RM, Friedman AC. Necrotizing fasciitis: CT characteristics. Radiology 1997;203:859-63. doi: 10.1148/radiology.203.3.9169717.

23 Thompson ML, Martin C. Management of necrotizing fasciitis infections. Orthopedics 2011;34:111-5. doi: 10.3928/01477447-2010122122.

24 Krieg A, Rohrborn A, Schulte Am Esch J, Schubert D, Poll LW, Ohmann C, Braunstein S, Knoefel WT. Necrotizing fasciitis: microbiological characteristics and predictors of postoperative 
outcome. Eur J Med Res 2009;14:30-6. doi: 10.1186/2047-783x-14-1-30.

25 Zimbelman J, Palmer A, Todd J. Improved outcome of clindamycin compared with betalactam antibiotic treatment for invasive Streptococcus pyogenes infection. Pediatr Infect Dis J 1999;18:1096-100. doi: 10.1097/00006454199912000-00014.

26 Shah J, Sharma AK, O’Donoghue JM, Mearns B, Johri A, Thomas V. Necrotising fasciitis of the breast. Br J Plast Surg 2001;54:67-8. doi: 10.1054/bjps.2000.3461.

27 Nizami S, Mohiuddin K, Mohsin e A, Zafar H, Memon MA. Necrotizing fasciitis of the breast. Breast J 2006;12:168-9. doi: 10.1111/j.1075122X.2006.00227.x.

28 Velchuru VR, Van Der Walt M, Sturzaker HG. Necrotizing fasciitis in a postmastectomy wound. Breast J 2006;12:72-4. doi: 10.1111/j.1075122X.2006.00186.x.

29 Flandrin A, Rouleau C, Azar CC, Dubon O, Giacalone PL. First report of a necrotising fasciitis of the breast following a core needle biopsy. Breast $J \quad 2009 ; 15: 199-201$. doi: 10.1111/j.15244741.2009.00697.x.

30 Rajakannu M, Kate V, Ananthakrishnan N. Necrotizing infection of the breast mimicking carcinoma. Breast $J$ 2006;12:266-7. doi: 10.1111/j.1075-122X.2006.00253.x.

31 Wani I, Bakshi I, Parray FQ, Malik AA, Wani RA, Shah M, Husasin I, Malik A, Wani S, Syed W. Breast gangrene. World J Emerg Surg 2011;6:29. doi: 10.1186/1749-7922-6-29.

32 Kaczynski J, Dillon M, Hilton J. Breast necrotising fasciitis managed by partial mastectomy. BMJ Case Rep 2012;2012. doi: 10.1136/bcr.02.2012.5816.

33 Green RJ, Dafoe DC, Raffin TA. Necrotizing fasciitis. Chest 1996;110:219-29. doi: 10.1378/chest.110.1.219.

34 Schurr C, Burghartz M, Miethke T, Kesting M, Hoang N, Staudenmaier R. Management of facial necrotizing fasciitis. Eur Arch Otorhinolaryngol 2009;266:325-31. doi: 10.1007/s00405-008-0870y.

35 Ray AM, Bressler K, Davis RE, Gallo JF, Patete ML. Cervicofacial necrotizing fasciitis. A devastating complication of blepharoplasty. Arch Otolaryngol Head Neck Surg 1997;123:633-6. doi: 10.1001/archotol.1997.01900060083014.

36 Schütz P, Joshi RM, Ibrahim HHH. Odontogenic necrotizing fasciitis of the neck and upper chest wall. Journal of Oral and Maxillofacial Surgery, Medicine, and Pathology 2012;24:32-5. doi: 10.1016/j.ajoms.2011.07.001.

37 Sumi Y, Ogura H, Nakamori Y, Ukai I, Tasaki O, Kuwagata Y, Shimazu T, Tanaka H, Sugimoto H. Nonoperative catheter management for cervical necrotizing fasciitis with and without descending necrotizing mediastinitis. Arch Otolaryngol Head Neck Surg 2008;134:750-6. doi: 10.1001/archotol.134.7.750.

38 Nakamori Y, Fujimi S, Ogura H, Kuwagata Y, Tanaka H, Shimazu T, Ueda T, Sugimoto H. Conventional open surgery versus percutaneous catheter drainage in the treatment of cervical necrotizing fasciitis and descending necrotizing mediastinitis. AJR Am $J$ Roentgenol 2004;182:1443-9. doi: 10.2214/ajr.182.6.1821443.

39 Muto T, Sato K, Kanazawa M. Necrotizing fasciitis of the neck and chest. Report of a case. International journal of oral and maxillofacial surgery 1992;21:236-8. doi: 10.1016/S09015027(05)80227-9.

40 Khadakkar SP, Harkare VV, Deosthale NV, Gupta A. Necrotising fasciitis of the neck and anterior chest wall. Indian J Otolaryngol Head Neck Surg 2011;63:87-9. doi: 10.1007/s12070-011-0209-7.

41 Konstantinov IE, Saxena P, Shehatha J, Mitchell A, Cherian S. Novel aeration technique for necrotizing fasciitis of the chest wall. Ann Thorac Surg 2008;86:1973-4. doi: 10.1016/j.athoracsur.2008.05.004.

42 Islam A, Oko M. Cervical necrotising fasciitis and descending mediastinitis secondary to unilateral tonsillitis: a case report. $J$ Med Case Rep 2008;2:368. doi: 10.1186/1752-1947-2-368.

43 Nakayama J, Busse R. An analysis of vulvar necrotizing fasciitis in the unique and ethnically diverse Hawaiian population. Hawaii Med $J$ 2010;69:13-6.

44 DeMuro J, Hanna A, Chalas E, Cunha B. Polymicrobial abdominal wall necrotizing fasciitis after cesarean section. Journal of surgical case reports 2012;2012:10.

45 Van Ammers P, Moore P, Sacho H. Necrotising fasciitis after caesarean section--association with non-steroidal anti-inflammatory drugs. A report of 3 cases. South African medical journal= SuidAfrikaanse tydskrif vir geneeskunde 1991;80:203-4.

46 Luksich JA, Holds JB, Hartstein ME. Conservative management of necrotizing fasciitis of the eyelids. 
Ophthalmology 2002;109:2118-22. doi: 10.1016/S0161-6420(02)01257-5.

47 Suner IJ, Meldrum ML, Johnson TE, Tse DT. Necrotizing fasciitis after cosmetic blepharoplasty. Am J Ophthalmol 1999;128:367-8. doi: 10.1016/s0002-9394(99)00134-8.

48 Lazzeri D, Lazzeri S, Figus M, Tascini C, Bocci G, Colizzi L, Giannotti G, Lorenzetti F, Gandini D, Danesi R. Periorbital necrotising fasciitis. British Journal of Ophthalmology 2010;94:1577-85.

49 Raja V, Job R, Hubbard A, Moriarty B. Periorbital necrotising fasciitis: delay in diagnosis results in loss of lower eyelid. International ophthalmology 2008;28:67-9.

$50 \mathrm{Lim}$ V, Amrith S. Necrotising fasciitis of the eyelid with toxic shock due to Pseudomonas aeruginosa. Singapore Med J 2010;51:e51-e3.

51 Lin C, Yeh FL, Lin JT, Ma H, Hwang CH, Shen BH, Fang RH. Necrotizing fasciitis of the head and neck: an analysis of 47 cases. Plast Reconstr Surg 2001;107:1684-93. doi: 10.1097/00006534200106000-00008.

52 Bahu SJ, Shibuya TY, Meleca RJ, Mathog RH, Yoo GH, Stachler RJ, Tyburski JG. Craniocervical necrotizing fasciitis: an 11-year experience. Otolaryngol Head Neck Surg 2001;125:245-52. doi: 10.1067/mhn.2001.118182.

53 Williams SR, Carruth JA, Brightwell AP. Necrotizing fasciitis of the face without significant trauma. Clin Otolaryngol Allied Sci 1992;17:34450. doi: 10.1111/j.1365-2273.1992.tb01010.x.

54 Chattar-Cora D, Tulsyan N, Cudjoe EA, Onime GD, Pyo DJ, Weinstein L. Necrotizing fasciitis of the head and neck: a report of two patients and review. Head Neck 2002;24:497-501. doi: 10.1002/hed.10060.
55 Sepúlveda A, Sastre N. Necrotizing fasciitis of the face and neck. Plastic and reconstructive surgery 1998;102:814-7.doi:

10.1097/00006534199809030-00028.

56 Nallathambi M, Ivatury R, Rohman M, Rao P, Stahl W. Craniocervical necrotizing fasciitis: critical factors in management. Canadian journal of surgery Journal canadien de chirurgie 1987;30:613.

57 Shindo ML, Nalbone VP, Dougherty WR. Necrotizing fasciitis of the face. Laryngoscope 1997;107:1071-9. doi: 10.1097/00005537199708000-00013.

58 Ameh EA, Mamuda AA, Musa HH, Chirdan LB, Shinkafi MS, Ogala WN. Necrotizing fasciitis of the scalp in a neonate. Ann Trop Paediatr 2001;21:91-3.

59 Siddiqi SF, Taylor PM. Necrotizing fasciitis of the scalp. A complication of fetal monitoring. Am J Dis Child 1982;136:226-8. doi: 10.1001/archpedi.1982.03970390040013.

60 Voros D, Pissiotis C, Georgantas D, Katsaragakis S, Antoniou S, Papadimitriou J. Role of early and extensive surgery in the treatment of severe necrotizing soft tissue infection. $\mathrm{Br} \quad J$ Surg 1993;80:1190-1. doi: 10.1002/bjs.1800800943.

61 Majeski J, Majeski E. Necrotizing fasciitis: improved survival with early recognition by tissue biopsy and aggressive surgical treatment. South Med J 1997;90:1065-8. doi: 10.1097/00007611199711000-00001.

62 Bilton BD, Zibari GB, McMillan RW, Aultman DF. Aggressive surgical management of necrotizing fasciitis serves to decrease mortality: a retrospective study/discussion. The American Surgeon 1998;64:397. 